\title{
Investment Opportunity Set sebagai Pemoderasi Pengaruh Profitabilitas, Kepemilikan Manajerial, dan Ukuran Perusahaan terhadap Kebijakan Utang
}

\section{Investment Opportunity Set as a Moderator of the Effect of Profitability, Managerial Ownership, and Company Size on Debt Policy}

\author{
Suriani Ginting*, Seti Eli Larosa \& Sonya Enda Natasha S Pandia* \\ Akuntansi, Sekolah Tinggi Ilmu Ekonomi Mikroskil, Indonesia
}

*Coresponding Email: suriani@mikrioskil.ac.id

\section{Abstrak}

Penelitian ini bertujuan untuk mengetahui dan menganalisis pengaruh Profitabilitas, Kepemilikan Manajerial, dan Ukuran Perusahaan terhadap Kebijakan Utang dengan Investment Opportunity Set sebagai variable moderasi. Populasi dalam penelitian ini sebanyak 177 Perusahaan. Metode pengambilan sampel yang digunakan adalah purposive sampling dan diperoleh 19 perusahaan yang menjadi Objek Penelitian. Metode pengujian data yang digunakan adalah analisis regresi linear berganda dan analisis regresi variable moderasi dengan metode uji nilai selisih mutlak. Hasil penelitian menunjukkan secara simultan variabel Profitabilitas, Kepemilikan Manajerial, dan Ukuran Perusahaan berpengaruh signifikan terhadap Kebijakan Utang. Secara Parsial, Variabel Profitabilitas dan Kepemilikan Manajerial berpengaruh signifikan terhadap Kebijakan Utang. Sedangkan Variabel Ukuran Perusahaan tidak berpengaruh terhadap Kebijakan Utang. Serta variabel Investment Opportunity Set tidak mampu memoderasi hubungan antara variabel Profitabilitas, Kepemilikan Manajerial, dan Ukuran Perusahaan terhadap kebijakan Utang.

Kata Kunci: Profitabilitas; Kepemilikan Manajerial; Kebijakan Utang; Ukuran Perusahaan

\footnotetext{
Abstract

This research aims to determine and analyze the influence of Profitability, Managerial Ownership, Firm Size in Debt Policy with Investment Opportunity Set as a moderating variable. The populations in this research were 177 companies. The sampling method in this research was purposive sampling and obtained 19 sample companies. Analysis of data method used multiple linear regression analysis and regression analysis moderating variable with absolute difference value method.The result of analysis shows that simultaneously Profitability, Managerial Ownership, Firm Size have a significant effect on Debt Policy. Partially, Profitability, Managerial Ownerdhip have a significant effect on Debt Policy. While Firm Size have a not significant on Debt Policy. And Investment Opportunity Set is not able to moderate the relationship between Profitability, Managerial Ownership, and Firm Size

Keyword: Profitabilitu; Managerial Ownership; Debt Policy; Firm Size.

How to Cite: Ginting, S., Larosa, S.E., \& Pandia, S.E.N.S. (2021). Invesment Opportunity Set Sebagai Pemoderasi Pengaruh Profitabilitas, Kepemilikan Manajerial, Dan Ukuran Perusahaan Terhadap Kebijakan Utang. Jurnal Akuntansi dan Bisnis : Jurnal Program Studi Akuntansi. 7 (1): 23-32.
} 


\section{PENDAHULUAN}

Persaingan bisnis yang semakin ketat dalam era globalisasi saat ini bermuara pada masalah tantangan dan peluang yang dihadapi perusahaan pada kekuatan dan kelemahan yang dimiliki oleh masing-masing perusahaan. Untuk mewujudkan salah satu tujuan perusahaan seperti perluasan usaha, perusahaan membutuhkan dana yang optimal. Dana dapat bersumber dari eksternal seperti pinjaman (jangka panjang atau jangka pendek) atau menerbitkan lembar saham baru (Initial Public Offering) yang dapat diperjual belikan kepada masyarakat di pasar modal maupun sumber internal seperti laba ditahan (retained earnings) yang merupakan hasil keuntungan dari kegiatan operasional perusahaan.

Pecking order theory menyatakan bahwa perusahaan lebih cenderung menggunakan dana internal terlebih dahulu untuk mendanai kegiatan operasionalnya dibandingkan dengan penggunaan dana yang bersumber dari eksternal (Chandra, 2015). Ketika sumber dana internal tidak lagi mencukupi maka perusahaan menggunakan dana eksternal dalam bentuk Utang. Kebijakan manajemen untuk menggunakan dana dalam bentuk Utang merupakan salah satu keputusan yang tepat dibandingkan dengan menerbitkan lembar saham yang baru dengan beberapa alasan. Pertama menerbitkan lembar saham yang baru akan menurunkan harga lembar saham yang lama, dimana akan berdampak harga saham turun. Kedua penggunaan dana dengan Utang dapat mengurangi jumlah pajak yang harus dibayarkan, karena net income akan terlihat rendah. Perusahaan harus dapat melunasi semua kewajiban kewajibannya kepada pihak kreditur seperti Utang pokok dan bunga tepat pada waktunya. Semakin tinggi proporsi Utang perusahaan maka semakin besar beban bunga yang ditanggung perusahaan. Agar perusahaan dapat tumbuh dan berkembang, maka perusahaan harus membuat suatu kebijakan Utang yang tepat agar tidak terjadi kegagalan dalam membayar Utang (Rahayu \& Yasa, 2018)

Pada penelitian ini memiliki Objek yaitu Perusahaan Manufaktur yang terdatar di Bursa Efek Indonesia. Perusahaan Manufaktur merupakan perusahaan yang bergerak dalam sektor pengolahan bahan baku mentah dan kemudian menjadi sebuah barang jadi yang siap untuk digunakan ataupun dijual kepada konsumen. Bursa Efek Indonesia sendiri mengkategorikan perusahaan manufaktur ke dalam beberapa sektor dan sub sektor, untuk sektor perusahaan manufaktur terbagi menjadi 3 yaitu sektor industry dasar dan kimia, sektor aneka industri, dan sektor industry barang konsumsi.

Profitabilitas merupakan salah satu faktor yang dapat mempengaruhi kebijakan Utang. Perusahaan yang memiliki profitabilitas yang tinggi dinilai mampu untuk mendanai aktivitas perusahaan. Sesuai dengan konsep Pecking Order Theory perusahaan lebih cenderung menggunakan dana internal terlebih dahulu untuk mendanai kegiatan operasionalnya dibandingkan dengan penggunaan dana yang bersumber dari eksternal (Chandra, 2015). Perusahaan akan menggunakan Utang yang relatif kecil karena keuntungan atau laba yang diperoleh perusahaan tidak semua dibayarkan kepada investor dalam bentuk dividen, tetapi juga disimpan dalam bentuk laba ditahan yang merupakan sumber pendanaan internal (Yap, 2016). Hasil ini sejalan dengan penelitian yang menunjukan bahwa profitabilitas mempengaruhi kebijakan Utang (Yap, 2016). Sedangkan pada penelitian lain menunjukan bahwa profitabilitas tidak berpengaruh negatif terhadap kebijakan Utang (Rahayu \& Yasa, 2018). Manajer perusahaan akan melakukan Investment Opportunity Set untuk menjamin keberlangsungan hidup perusahaan di masa yang akan datang, sehingga Investment Opportunity Set yang tinggi diduga akan memperkuat pengaruh profitabilitas terhadap kebijakan Utang.

Perusahaan dengan kepemilikan manajerial yang tinggi mempunyai dampak terhadap keputusan kebijakan dalam penggunaan Utang karena manajemen perusahaan 
akan berhati-hati dalam menggunakan Utang untuk menghindari resiko pailit dalam perusahaan tersebut. Hal ini sejalan dengan penelitian terdahulu yang menunjukan bahwa kepemilikan manajerial berpengaruh terhadap kebijakan Utang (Rahayu \& Yasa, 2018). Sedangkan pada penelitian lain menunjukan bahwa kepemilikan manajerial tidak berpengaruh terhadap kebijakan Utang (Soraya \& Permanasari, 2017). Manajer perusahaan yang memiliki saham dari perusahaan tersebut akan lebih berhati-hati dalam mengambil keputusan dalam kebijakan Utang, biasanya manajer akan lebih memilih melakukan investasi untuk memperoleh manfaat di masa yang akan datang sehingga Investment Opportunity Set yang tinggi diduga akan memperkuat pengaruh kepemilikan manajerial terhadap kebijakan Utang.

Ukuran perusahaan salah satu variabel yang berkaitan dengan Utang. Perusahaan besar yang telah terdiversifikasi akan lebih mudah dalam memasuki pasar modal, menerima penilaian kredit yang tinggi dari bank komersial untuk Utang-Utang yang diterbitkan dan membayar tingkat bunga yang lebih rendah pada Utangnya (Trisnawati, 2016). Hal ini sejalan dengan penelitian yang menunjukan bahwa ukuran perusahaan berpengaruh terhadap kebijakan Utang (Soraya \& Permanasari, 2017). Sedangkan pada penelitian lain menunjukan bahwa ukuran perusahaan tidak berpengaruh terhadap kebijakan Utang (Trisnawati, 2016). Ukuran Perusahaan dapat diartikan sebagai suatu skala dimana dapat diklasifikasikan besar kecilnya perusahaan dengan berbagai cara seperti dinyatakan kedalam total aktiva (Haryadi, 2016). Manajer perusahaan akan melakukan investasi untuk meningkatkan ukuran perusahaan, sehingga Investment Opportunity Set yang tinggi diduga dapat memperkuat hubungan ukuran perusahaan terhadap kebijakan Utang.

Rumusan masalah pada penelitian ini ialah Apakah Profitabilitas, Kepemilikan Manajerial, dan Ukuran Perusahaan berpengaruh secara simultan maupun parsial terhadap Kebijakan Utang pada Perusahaan Manufaktur yang terdaftar di Bursa Efek Indonesia Periode 2015-2018? dan Apakah Investment Opportunity Set mampu memoderasi hubungan antara Profitabilitas, Kepemilikan Manajerial, dan Ukuran Perusahaan dengan Kebijakan Utang pada Perusahaan Manufaktur yang terdaftar di Bursa Efek Indonesia Periode 2015-2018?

Pada penelitian ini menggunakan Investment Opportunity Set sebagai variabel moderasi. Ketika manajemen perusahaan melakukan Investment Opportunity Set maka dapat menjamin keberlangsungan hidup perusahaan sehingga diharapkan dengan adanya Investment Opportunity Set mampu memoderasi hubungan antara Profitabilitas, Kepemilikan Manajerial, dan Ukuran Perusahaan terhadap Kebijakan Utang. Pada Penelitian terdahulu Investment Opportunity Set tidak mampu memperkuat hubungan antara Profitabilitas dan Kepemilikan Manajerial Terhadap Kebijakan Utang (Rahayu \& Yasa, 2018).

Perusahaan dengan tingkat pengembalian atas investasi yang sangat tinggi ternyata menggunakan Utang dalam jumlah yang relatif sedikit. Tingkat pengembalian yang tinggi memungkinkan perusahaan-perusahaan melakukan sebagian besar pendanaannya melalui dana yang dihasilkan secara internal (Bringham \& Houston, 2011). Perusahaan yang memiliki profitabilitas yang tinggi maka akan berpengaruh pada keputusan terkait Utang perusahaan, terutama jika diketahui investment opportunity set yang tinggi maka kebijakan Utang akan rendah. Hal ini disebabkan manajer lebih memilih untuk berinvestasi karena memiliki kesempatan investasi yang tinggi dan tidak ingin melewatkan kesempatan untuk mendapat keuntungan dimasa yang akan datang. Pada penelitian yang pernah dilakukan, menunjukan bahwa profitabilitas mempengaruhi 
kebijakan Utang (Soraya \& Permanasari, 2017). Hasil Penelitian terdahulu menunjukkan bahwa investment opportunity set tidak mampu memperkuat hubungan Profitabilitas dengan Kebijakan Utang (Rahayu \& Yasa, 2018).

Berdasarkan uraian di atas, maka hipotesis dalam penelitian adalah sebagai berikut: H1a: Profitabilitas berpengaruh terhadap kebijakan Utang.

H2a: Investment Opportunity Set mampu memoderasi hubungan antara profitabilitas dengan kebijakan Utang.

Insentif yang diberikan berupa kepemilikan saham dapat memotivasi pihak manajemen untuk meningkatkan kinerjanya dalam mengelola perusahaan. Semakin sedikit persentase kepemilikan para manajer, semakin sedikit kecenderungan mereka akan bertindak secara konsisten untuk memaksimalkan kesejahteraan para pemegang saham (Van Horne \& Wachowicz, 2012). Manajer perusahaan yang memiliki saham dari perusahaan tersebut akan lebih berhati-hati dalam mengambil keputusan dalam kebijakan Utang. Perusahaan lebih memilih untuk memanfaatkan investment opportunity set dan manajer tidak ingin menyiakan kesempatan untuk mendapat keuntungan yang besar dalam berinvestasi. Pada penelitian yang pernah dilakukan, menunjukan bahwa kepemilikan manajerial berpengaruh terhadap kebijakan Utang (Rahayu \& Yasa, 2018). Pada penelitian ini menggunakan Investment Opportunity Set sebagai variabel moderasi karena ketika manajemen perusahaan mempunyai Investment Opportunity Set dapat menjamin keberlangsungan hidup perusahaan sehingga diharapkan dengan adanya Investment Opportunity Set mampu memoderasi hubungan antara Profitabilitas dengan Kebijakan Utang (Rahayu \& Yasa, 2018)

Berdasarkan uraian di atas, maka hipotesis dalam penelitian adalah sebagai berikut: H1b: Kepemilikan Manajerial berpengaruh terhadap kebijakan Utang.

H2b: Investment Opportunity Set mampu memoderasi hubungan antara kepemilikan manajerial dengan kebijakan Utang.

Perusahaan kecil harus memiliki modal tetap sebelum pemberi pinjaman bersedia memberikan pinjaman, sebagian besar bank menolak pinjaman untuk dijadikan modal karena potensi tingkat pengembalian benar-benar terbatas pada bunga pinjaman dan potensi kerugian akan lebih besar daripada keuntungannya (Hamali, 2016). Sedangkan perusahaan yang besar akan lebih mudah dalam memperoleh pinjaman dari bank karena telah mendapat penilaian kredit yang tinggi dari bank komersial untuk Utang-Utang yang diterbitkan. Pada penelitian yang pernah dilakukan, menunjukan bahwa ukuran perusahaan berpengaruh terhadap kebijakan Utang (Yap, 2016).

Berdasarkan uraian diatas, maka hipotesis dalam penelitian adalah sebagai berikut: H1c: Ukuran Perusahaan berpengaruh terhadap kebijakan Utang.

H2c: Investment Opportunity Set mampu memoderasi hubungan antara ukuran perusahaan dengan kebijakan Utang

\section{METODE PENELITIAN}

Populasi yang digunakan dalam penelitian ini adalah perusahaan manufaktur yang terdaftar di Bursa Efek Indonesia (BEI) pada periode 2015-2019. Teknik pengambilan sampel dalam penelitian ini adalah menggunakan metode Purposive Sampling yaitu tipe pemilihan sampel tidak secara acak tetapi yang informasinya diperoleh dengan menggunakan pertimbangan tertentu dan umumnya disesuaikan dengan masalah penelitian dan tujuan penelitian. 
Variabel Dependen: Kebijakan Utang (DER). Debt to equity ratio untuk setiap perusahaan tentu akan berbeda-beda tergantung dari karakteristik bisnis dan keberagaman arus kasnya. Perusahaan dengan arus kas yang stabil biasanya memiliki rasio yang lebih tinggi dari rasio kas yang kurang stabil (Kasmir, 2018). Besar kecilnya pembiayaan suatu perusahaan dapat dilihat dari debt to equity ratio. Besar kecilnya debt to equity ratio ini mempunyai implikasi terhadap besar kecilnya resiko dari suatu perusahaan tersebut. Rumus dari debt to equity ratio yang merupakan proksi dari kebijakan Utang adalah sebagai berikut:

$$
\text { Debt to equity ratio }=\frac{\text { Total Kewajiban }(\text { debt })}{\text { Ekuitas }(\text { equity })}
$$

Variabel Moderasi: Investment Opportunity Set. Pada penelitian ini investment opportunity set diproksikan dengan market to book value equity. Rasio ini mengukur penilaian pasar keuangan terhadap manajemen dan organisasi perusahaan sebagai going concern. Nilai buku saham mencerminkan nilai historis dari aktiva perusahaan. Perusahaan yang dikelola dengan baik dan beroperasi secara efisien dapat memiliki nilai pasar yang lebih tinggi daripada nilai buku asetnya. Rata-rata industri pada market to book value equity adalah 1,8. Market to book value equity dianggap baik jika diatas dari 1,8 (Brigham \& Ehrhardt, 2016). Rumus dari market to book value of equity (MBVE) yang merupakan proksi dari investment opportunity set adalah sebagai berikut:

$$
M B V E=\frac{(\text { Price per share })(\text { Total number of shares })}{\text { Total common equity }}
$$

\section{Variabel Independen:}

Profitabilitas. Pada penelitian ini profitabilitas diukur dengan return on assets. Return on asset merupakan kemampuan perusahaan menggunakan seluruh aktiva yang dimiliki untuk menghasilkan laba setelah pajak (Sudana, 2011). Rasio ini sangat penting bagi pihak manajemen untuk mengevaluasi efektivitas dan efisiensi manajemen perusahaan dalam mengelola seluruh aktiva. Rumus dari return on assets yang merupakan proksi dari profitabilitas adalah sebagai berikut:

$$
\text { Return on Assets }=\frac{\text { Earning after taxes }}{\text { Total Assets }}
$$

Kepemilikan Manajerial. Kepemilikan manajerial adalah kepemilikan oleh pihak manajemen perusahaan (Subagyo, Masruroh, \& Bastian, 2018). Pihak manajemen perusahaan merupakan pihak yang ditunjuk oleh pemilik dan diberi kewenangan dalam pengambilan keputusan seperti keputusan investasi, keputusan pendanaan, keputusan manajemen aset dan penciptaan nilai perusahaan dengan harapan bertindak demi kepentingan para pemegang saham. Kepemilikan manajerial dapat diukur dengan rumus sebagai berikut:

$$
\text { Kepemilikan Manajerial }=\frac{\text { Jumlah saham yang dimiliki manajer }}{\text { Jumlah saham yang beredar }} \times 100 \%
$$

Ukuran Perusahaan. Ukuran perusahaan adalah suatu skala dimana dapat dibagi menjadi empat yaitu (Undang-Undang Republik Indonesia Nomor 17 Tahun 2012 tentang Perkoperasian \& Undang-Undang Republik Indonesia Nomor 20 Tahun 2008 tentang Usaha Mikro, Kecil dan Menengah, 2016). Ukuran perusahaan dapat diukur dari:

$$
\text { Ukuran Perusahaan }=\ln (\text { total aset })
$$


Metode analisis data dalam penelitian ini adalah statistic deskriptif, analisis regresi berganda (Multiple Regression Analysis) dan uji nilai selisih mutlak untuk variabel moderasi. Data penelitian ini diolah dengan menggunakan program Statistical Package for Social Science (SPSS). Analisis regresi berganda bermaksud untuk meramalkan bagaimana keadaan variabel dependen bila dihubungkan dengan dua atau lebih variabel independen. Untuk menguji variabel moderasi dipilih menggunakan uji nilai selisih mutlak. Dengan persamaan regresi linear berganda adalah sebagai berikut:

$$
\mathrm{Y}=\alpha+\beta_{1} \mathrm{X}_{1}+\beta_{2} \mathrm{X}_{2}+\beta_{3} \mathrm{X}_{3}+e
$$

Untuk menguji kemampuan variabel $\mathrm{Z}$ (variabel moderasi) dalam mempengaruhi pengaruh X terhadap Y, dilakukan dengan uji Nilai Selisih Mutlak. Persamaan regresi sebagai berikut:

$$
Y=\alpha+\beta_{1} X_{1}+\beta_{2} X_{2}+\beta_{3} X_{3}+\beta_{4} Z+\beta_{5}\left|X_{1}-Z\right|+\beta_{6}\left|X_{2}-Z\right|+\beta_{7}\left|X_{3}-Z\right|+e
$$

\section{HASIL DAN PEMBAHASAN}

\section{Pengujian Hipotesis Pertama Setelah Transformasi Data}

Uji Signifikansi Simultan (Uji Statistik - F). Berdasarkan Tabel 1 dapat dilihat bahwa nilai $F_{\text {hitung }}$ menunjukkan nilai 8,894 dengan nilai $F_{\text {tabel }}$ sebesar 2,70 sehingga diperoleh $\left(\mathrm{F}_{\text {hitung }}=8,894\right)>\left(\mathrm{F}_{\text {tabel }}=2,70\right)$ dan nilai signifikansi yang lebih kecil dari 0,05 $(0,000<0,05)$. Sehingga dapat disimpulkan bahwa variabel ROA, Kepemilikan Manajerial, dan Ukuran Perusahaan secara simultan berpengaruh signifikan terhadap Kebijakan Utang pada perusahaan Manufaktur yang terdaftar di Bursa Efek Indonesia (BEI) periode 2015-2019.

Tabel 1 Hasil Pengujian Hipotesis Pertama Uji Simultan (Uji Statistik-F)

\begin{tabular}{ll|r|r|r|r|r}
\hline Model & & Sum of Squares & df & Mean Square & F & \multicolumn{1}{c}{ Sig. } \\
\hline \multirow{2}{*}{1} & Regression & 18,014 & 3 & 6,005 & 8,894 & \multirow{2}{*}{$000^{\mathrm{b}}$} \\
\cline { 2 - 6 } & Residual & 61,439 & 91 &, 675 & & \\
\cline { 2 - 6 } & Total & 79,453 & 94 & & & \\
\hline
\end{tabular}

a. Dependent Variable: LN_DER

b. Predictors: (Constant), LN_Ukuran Perusahaan, LN_ROA, LN_Kepemilikan Manajerial

Uji Signifikansi Parsial (Uji Statistik F). Berdasarkan Tabel 2 dapat dilihat bahwa ROA dan Kepemilikan Manajerial berpengaruh Signifikan terhadap Kebijakan Utang. Sedangkan Ukuran Perusahaan tidak berpengaruh terhadap Kebijakan Utang

\begin{tabular}{|c|c|c|c|c|c|c|}
\hline \multirow{2}{*}{\multicolumn{2}{|c|}{ Model }} & \multicolumn{2}{|c|}{ Unstandardized Coefficients } & \multirow{2}{*}{$\begin{array}{c}\begin{array}{c}\text { Standardized } \\
\text { Coefficients }\end{array} \\
\text { Beta } \\
\end{array}$} & \multirow[b]{2}{*}{$\mathrm{t}$} & \multirow[b]{2}{*}{ Sig. } \\
\hline & & $\mathrm{B}$ & Std. Error & & & \\
\hline \multirow[t]{4}{*}{1} & (Constant) & $-3,252$ & 3,356 & &,- 969 & ,335 \\
\hline & LN_ROA &,- 121 & ,056 &,- 202 & $-2,151$ & 034 \\
\hline & LN_Kepemilikan Manajerial &,- 134 & 035 &,- 378 & $-3,814$ & 000 \\
\hline & LN_Ukuran Perusahaan & ,528 & 1,017 & ,051 & ,519 & 605 \\
\hline
\end{tabular}

Tabel 2 Hasil Pengujian Hipotesis Pertama Uji Parsial (Uji Statistik-t)

a. Dependent Variable: LN_DER 
Uji Koefisien Determinasi, Berdasarkan hasil pengujian Tabel 3 dapat dilihat bahwa nilai Adjusted $R$ Square (Adjusted $\mathrm{R}^{2}$ ) yang diperoleh adalah sebesar 0,201 yang berarti bahwa variabel Profitabilitas (ROA), Kepemilikan Manajerial,dan Ukuran Perusahaan sebesar 0,201 atau sebesar 20,1\% sedangkan sisanya sebesar 79,9\% dijelaskan oleh variabel lain yang tidak diteliti dalam penelitian ini.

Tabel 3 Hasil Pengujian Hipotesis Pertama Koefisien Determinasi ( $\mathbf{R}^{2}$ )

\begin{tabular}{|c|c|c|c|c|}
\hline Model & $\mathrm{R}$ & R Square & Adjusted R Square & Std. Error of the Estimate \\
\hline 1 & $476^{\mathrm{a}}$ & 227 & ,201 & ,82168 \\
\hline
\end{tabular}

\section{Pengujian Hipotesis Kedua Setelah Transformasi Data}

Hasil pengujian hipotesis kedua dapat dilihat pada Tabel 4 sebagai berikut: Tabel 4 Hasil Pengujian Hipotesis Kedua

\begin{tabular}{|c|c|c|c|c|c|c|}
\hline \multirow{2}{*}{\multicolumn{2}{|c|}{ Model }} & \multicolumn{2}{|c|}{$\begin{array}{l}\text { Unstandardized } \\
\text { Coefficients }\end{array}$} & \multirow{2}{*}{$\begin{array}{c}\begin{array}{c}\text { Standardized } \\
\text { Coefficients }\end{array} \\
\text { Beta } \\
\end{array}$} & \multirow[b]{2}{*}{ t } & \multirow[b]{2}{*}{ Sig. } \\
\hline & & $\mathrm{B}$ & Std. Error & & & \\
\hline \multirow[t]{8}{*}{1} & (Constant) &,- 377 & ,217 & & $-1,735$ & ,086 \\
\hline & Zscore (LN_ROA) &,- 318 & ,114 &,- 346 & $-2,777$ & ,007 \\
\hline & Zscore (LN_Kepemilikan Manajerial) &,- 263 & 104 &,- 287 & $-2,545$ & 013 \\
\hline & Zscore(LN_Ukuran Perusahaan) & 024 & 092 & ,026 & ,260 & ,795 \\
\hline & Zscore (IOS) & ,188 & 093 & ,204 & 2,027 & 046 \\
\hline & Abs_Z ROA &,- 166 & 127 &,- 165 & $-1,303$ & 196 \\
\hline & Abs_Z Kepemilikan Manajerial &,- 200 & , 148 &,- 132 & $-1,350$ & ,181 \\
\hline & Abs_Z Ukuran Perusahaan & 144 & 135, & 119, & 1,069 & 288 \\
\hline
\end{tabular}

a. Dependent Variable: LN_DER

Pengujian hipotesis kedua dilakukan dengan menggunakan metode pengujian selisih mutlak. Berdasarkan Tabel 4dapat disimpulkan bahwa:

1. Nilai Selisih Mutlak Abs_ROA dengan IOS memiliki (nilai sig $=0,196$ ) >0,05 yang berarti bahwa $\mathrm{H}_{2 a}$ ditolak dan $\mathrm{H}_{2}{ }_{0}$ diterima yaitu IOS tidak mampu memoderasi hubungan variabel Profitabilitas (ROA) dengan Kebijakan Utang ( LN_DER) pada perusahaan Manufaktur yang terdaftar di Bursa Efek Indonesia periode 2015-2019

2. Nilai Selisih Mutlak Abs_Kepemilikan Manajerial dengan IOS memiliki (nilai sig = $0,181)>0,05$ yang berarti bahwa $\mathrm{H}_{2 b}$ ditolak dan $\mathrm{H} 2{ }_{0}$ diterima yaitu IOS tidak mampu memoderasi hubungan variabel Kepemilikan Manajerial dengan Kebijakan Utang (LN_DER) pada perusahaan Manufaktur yang terdaftar di Bursa Efek Indonesia periode 2015-2019

3. Nilai Selisih Mutlak Abs_Ukuran Perusahaan dengan IOS memiliki (nilai sig = 0,288) > 0,05 yang berarti bahwa bahwa $\mathrm{H}_{2 c}$ ditolak dan $\mathrm{H} 2{ }_{0}$ diterima yaitu IOS tidak mampu memoderasi hubungan variabel Ukuran Perusahaan dengan Kebijakan Utang (LnDER) pada perusahaan Manufaktur yang terdaftar di Bursa Efek Indonesia periode 2015-2019

\section{Pengaruh Profitabilitas Terhadap Kebijakan Utang dengan Investment opportunity Set Sebagai Variabel Moderasi}

Dari hasil penelitian ini diketahui bahwa Profitabilitas berpengaruh signifikan terhadap Kebijakan Utang. Hasil penelitian ini sejalan dengan penelitian terdahulu yang menyatakan bahwa Profitabilitas berpengaruh signifikan negative terhadap Kebijakan 
Utang (Sha, 2018). Namun hasil penelitian ini tidak sejalan dengan penelitian lain yang menyatakan bahwa Profitabilitas tidak beperngaruh terhadap Kebijakan Utang (Rahayu \& Yasa, 2018). Ketika Perusahaan memiliki nilai Profitabilitas yang tinggi maka hal tersebut menunjukkan bahwa perusahaan memiliki kemampuan dalam menghasilkan laba dari asset yang dimiliki oleh perusahaan. Sehingga perusahaan akan mampu mengurangi sumber pendanaan dari utang. Oleh karena itu semakin tinggi Profitabilitas maka perusahaan akan membuat kebijakan untuk mengurangi sumber pendanaan yang diperolah dari Utang.

Dalam penelitian ini IOS tidak mampu memoderasi hubungan Profitabilitas dengan Kebijakan Utang. IOS diproksikan dengan market to book value equity yang mengukur penilaian pasar terhadap manajemen perusahaan. Nilai IOS yang tinggi maupun rendah tidak menjadi tolok ukur utama bagi perusahaan di dalam menentukan Kebijakan Utang dikarenakan perusahaan yang memiliki nilai profitabilitas yang tinggi sudah efektif dalam mengelola asset untuk menghasilkan laba, sehingga hal tersebut sudah cukup bagi pihak manajemen perusahaan dalam menentukan keputusan dalam menentukan kebijakan Utang yang akan diambil oleh perusahaan.

\section{Pengaruh Kepemilikan Manajerial Terhadap Kebijakan Utang dengan Investment opportunity Set Sebagai Variabel Moderasi}

Dari hasil penelitian ini diketahui bahwa Kepemilikan Manajerial berpengaruh signifikan terhadap Kebijakan Utang. Hasil penelitian ini sejalan dengan penelitian terdahulu yang menyatakan bahwa Kepemilikan Manajerial berpengaruh signifikan negative terhadap Kebijakan Utang (Rahayu \& Yasa, 2018). Namun hasil penelitian ini tidak sejalan dengan penelitian lain yang menyatakan bahwa Kepemilikan Manajerial tidak beperngaruh terhadap Kebijakan Utang (Soraya \& Permanasari, 2017). Peran pihak manajemen dalam mengambil kebijakan pada perusahaan akan berupaya untuk menurunkan sumber pendanaan yang berasal dari Utang sehingga mampu mengelola kebijakan Utang perusahaan dengan baik.

Dalam penelitian ini IOS tidak mampu memoderasi hubungan Kepemilikan Manajerial dengan Kebijakan Utang. Hal tersebut dikarenakan pihak Perusahaan telah memiliki pihak Manjerial yang sudah efektif sehingga dalam mengambil kebijakan Utang pihak perusahaan bukan menjadikan IOS sebagai salah acuan yang harus dipertimbangkan dalam mengambil suatu kebijakan Utang pada perusahaan.

\section{Pengaruh Ukuran Perusahaan Terhadap Kebijakan Utang dengan Investment opportunity Set Sebagai Variabel Moderasi}

Dari hasil penelitian ini diketahui bahwa Ukuran Perusahaan tidak berpengaruh terhadap Kebijakan Utang. Hasil penelitian ini sejalan dengan penelitian sebelumnya yang menyatakan bahwa Ukuran Perusahaan tidak berpengaruh terhadap Kebijakan Utang (Trisnawati, 2016). Namun hasil penelitian ini tidak sejalan dengan penelitian lain yang menyatakan bahwa Ukuran Perusahaan berpengaruh terhadap Kebijakan Utang (Sha, 2018). Kebijakan Utang merupakan keputusan yang diambil oleh pihak Manajemen Perusahan untuk menentukan sumber pendanaan yang diperoleh dari modal sendiri atau pihak luar seperti kreditur dan pemberi pinjaman. Besar kecilnya perusahaan tidak menjadi pertimbangan bagi pihak manajemen untuk menentukan kebijakan Utangnya dikarenakan baik perusahaan besar maupun perusahaan kecil sama-sama membutuhkan kebijakan Utang.

Dalam penelitian ini IOS tidak mampu memoderasi hubungan Ukuran Perusahaan dengan Kebijakan Utang. Hal tersebut dikarenakan IOS bukan menjadi patokan utama 
bagi pihak menajemen perusahaan dalam menentukan kebijakan Utang karena penerapan kebijakan Utang yang diputuskan oleh pihak manajemen perusahaan dilihat berdasarkan bagaimana kondisi internal perusahaan

\section{SIMPULAN}

Adapun kesimpulan dalam penelitian ini adalah bahwa Profitabilitas dan Kepemilikan Manajerial berpengaruh signifikan terhadap Kebijakan Utang. Hasil dari penelitian ini sejalan dengan Pecking order theory yang menyatakan bahwa perusahaan lebih cenderung menggunakan dana internal terlebih dahulu untuk mendanai kegiatan operasionalnya dibandingkan dengan penggunaan dana yang bersumber dari eksternal. Sedangkan variabel Ukuran Perusahaan tidak berpengaruh terhadap Kebijakan Utang. Variabel Invesment Opportunity Set tidak mampu memoderasi hubungan antara Profitabilitas, Kepemilikan Manajerial, dan Ukuran Perusahaan. Saran yang dapat diberikan pada penelitian ini adalah ketika menentukan Kebijakan Utang, pihak manajemen perlu meningkatkan Profitabilitas dan peran pihak manajerial dikarenakan Profitabilitas merupakan gambaran bagaimana suatu perusahaan mampu di dalam mengelola asetnya dengan efektif untuk menghasilkan laba

\section{DAFTAR PUSTAKA}

Brigham, E. F., \& Ehrhardt, M. C. (2016). Financial Statement : Theory and Practice. USA: Cengage Learning.

Bringham, E. F., \& Houston, J. F. (2011). Dasar-Dasar Manajemen Keuangan Essentials Of Financial Management. Jakarta: Salemba Empat.

Chandra, T. (2015). Hutang di Indonesia. Pekan Baru: Zifatma Publishing.

Hamali, A. Y. (2016). Pemahaman Strategi Bisnis \& Kewirausahaan. Jakarta: Prenadamedia Group.

Haryadi, E. (2016, JULI). Pengaruh Size Perusahaan, Keputusan Pendanaan, Profitabilitas Dan Keputusan Investasi Terhadap Nilai Perusahaan. Jurnal Akuntansi, 3, 84-100.

Kasmir. (2018). Analisis Laporan Keuangan. Jakarta: PT. RajaGrafindo Persada.

Ma'ruf, W. (2017, Juni 06). Jakarta Kyoei Steel Tawarkan Utang Jadi Saham. Retrieved 01 18, 2020, from Inilahcom: https://inilah.com/news/2383499/jakarta-kyoei-steel-tawarkan-utang-jadi-saham

Nurfitriyani, A. (2016, Februari 19). BIMA Tukar Utang Jadi Saham. Retrieved 01 17, 2020, from Warta Ekonomi: https://www.wartaekonomi.co.id/read90941/bima-tukar-utang-jadi-saham.html

Rahayu, A. P., \& Yasa, G. W. (2018). Investment Opportunity Set (IOS) Sebagai Pemoderasi Pengaruh Profitabilitas Dan Kepemilikan Manajerial Terhadap Kebijakan Hutang. E-Jurnal Akuntansi Universitas Udayana, 22.2, 856-883.

Sha, T. L. (2018). Faktor-Faktor Yang Mempengaruhi Kebijakan Hutang Perusahaan Manufaktur di Bursa Efek Indonesia. Jurnal Ekonomi, XXIII, 159-174.

Soraya, \& Permanasari, M. (2017). Faktor-Faktor Yang Mempengaruhi Kebijakan Hutang Perusahaan Non Keuangan Publik. Jurnal Bisnis dan Akuntansi, 19, 103-116.

Subagyo, Masruroh, N. A., \& Bastian, I. (2018). Akuntansi Manajemen Berbasis Desain. Yogyakarta: Gajah Mada University Press.

Sudana, I. M. (2011). Manajemen Keuangan Perusahaan Teori \& Praktek. Surabaya: Penerbit Erlangga.

Sugianto, D. (2018, July 18). Produsen Taro Akui Tak Sanggup Bayar Utang. Retrieved 01 15, 2020, from detikFinance: https://finance.detik.com/bursa-dan-valas/d-4121328/produsen-taro-akui-taksanggup-bayar-utang

Trisnawati, I. (2016). Faktor-Faktor Yang Mempengaruhi Kebijakan Hutang Pada Perusahaan Non Keuangan Yang Terdaftar di Bursa Efek Indonesia. Jurnal Bisnis dan Akuntansi, 18(1), 33-42.

Undang-Undang Republik Indonesia Nomor 17 Tahun 2012 tentang Perkoperasian \& Undang-Undang Republik Indonesia Nomor 20 Tahun 2008 tentang Usaha Mikro, Kecil dan Menengah. (2016). Bandung: Citra Umbara.

Van Horne, J. C., \& Wachowicz, J. M. (2012). Prinsip-Prinsip Manajemen Keuangan. Jakarta: Salemba Empat.

Yap, S. (2016). Pengaruh Karakteristik Perusahaan, Rasio Keuangan, Corporate Tax Rate Dan Non Debt Tax Shield Terhadap Kebijakan Hutang Pada Perusahaan Food And Beverages. Jurnal Bisnis Dan Akuntansi, 18, 176-186. 